\title{
Photosynthesis and fish production: Hypothetical effects of climatic change and pollution
}

\author{
W. Greve ${ }^{1} \&$ T. R. Parsons ${ }^{2}$ \\ 1 Biologische Anstalt Helgoland (Meeresstation); \\ Helgoland, Federal Republic of Germany, \\ and \\ 2 Institute of Oceanography, University of British Columbia; \\ Vancouver, B. C., Canada
}

\begin{abstract}
Overall comparisons of marine pelagic productions in different systems are speculative to a high degree. Yet they often bring to our attention processes which have not been sufficiently investigated. One such process may be the decrease of fish production due to the change in the diatom/flagellate ratio. The following hypothesis is discussed in the light of recent investigations: An increasing development of flagellates caused by some types of pollution or climatic changes not only may increase the number of trophic levels and thereby, decrease fish production, but also may cause a change in the flow of biomass from fish to ctenophores and other planktonic predarors, thereby again decreasing the harvest available for human consumption.
\end{abstract}

\section{INTRODUCTION}

Ryther (1969) considered the number of trophic levels in marine pelagic communities and showed that the quantity of fishable resources was related to the length of the food chain. In Ryther's hypothesis it was shown that if a phytoplankton community was governed by small flagellates, then the number of links in any subsequent food chain resulted in a much lower transfer efficiency to harvestable fish resources compared with a food chain in which large phytoplankton cells could be converted to harvestable fish, within only one or two trophic levels of the primary producers.

\section{HYPOTHESIS}

An alternate, but not necessarily mutually exclusive hypothesis, is to consider structural elements in the food web consisting of two branches as represented by a basic difference in planktivorous feeding. The first feeding method is characterised by visual searching and capturing of zooplankton; this will be referred to as raptorial planktivorous feeding and is generally characteristic of planktivorous fish. The second 
feeding method is characterised by indiscriminate filtering; this will be referred to as planktivorous filter feeding and is generally characteristic of the planktonic "jellies", including both ctenophores and medusae. Beside and between these two branches in the food web of the sea exist a host of alternatives. For example, visual filter feeding occurs among the anchovy, and raptorial feeding among planktonic animals is exemplified by the chaetognaths. It is not our purpose to discuss all these possible feeding strategies but it is our suggestion that the two principal planktivorous feeding or foraging strategies given above are sufficiently important, in many temperate marine communities, to cause a dominance which may have as much influence on the yield of fish to man as was shown in the simpler food-chain efficiency model, suggested by Ryther (1969).

Our present hypothesis is based on literature reports but its future will depend on verification or refutation through more careful examination of ecological data collected by marine laboratories in temperate regions of the world. In summary, we suggest that two principal pathways exist for the transfer of energy up the food web of the sea. These are:

Nanophytoplankton (e.g. small flagellates) $\rightarrow$ small zooplankton $\rightarrow$ ctenophores or medusae or, alternately,

Microphytoplankton (e.g. large diatoms) $\rightarrow$ large zooplankton $\rightarrow$ young fish

\section{EVIDENCE}

The evidence for the existence of these two pathways in the marine food web can be presented as follows using references from the literature and some more recent data obtained from large plastic containers, (Parsons, 1974; Grice et al., 1977).

Communities predominated by small flagellates and others predominated by larger phytoplankton have been discussed in recent papers by Semina (1972), Parsons \& Takahashi (1973) and Wangersky (1977). The reason for the predominance of different sizes of phytoplankton cells has been generally related to hydrographic conditions - including depth of mixing, nutrient concentration and the availability of light, as well as to biological conditions, such as the effect of zooplankton grazing (Malone, 1971). More recently, however, it has been shown that small flagellate dominance can also be caused by pollutants, such as hydrocarbons (Dunstan et al., 1975; Parsons et al., 1976) which may enhance the growth of certain species of nanoplankton. This is illustrated in Figure 1 where the growth of a population of nanoplankton (ca. $10 \mu \mathrm{m}$ diameter) is shown following treatment of an enclosed environment with 40 and $80 \mathrm{ppb}$ of petroleum hydrocarbons.

From the examination of species present at this time it was apparent that the principal organism causing the increase in the particle-size spectrum was Chrysochromulina kappa. The same genus of flagellate was found to be plentiful among the plankton after the "Torrey Canyon" spill (Smith, 1968). In addition it has been shown during other CEPEX experiments (e.g. Thomas \& Seibert, in press) that a low concentration of copper may also cause a decrease in the number of diatoms and an 
increase in the flagellate community. Subba Rao (in: Dickie, 1973) and Fisher (1976) have further suggested that observed natural changes towards small phytoplankton in different marine environments are the result of various forms of pollution. Thus, the determinant factor in evolving either of the two food chains postulated above can be ascribed not only to natural environmental conditions, but may also be the result of pollution.

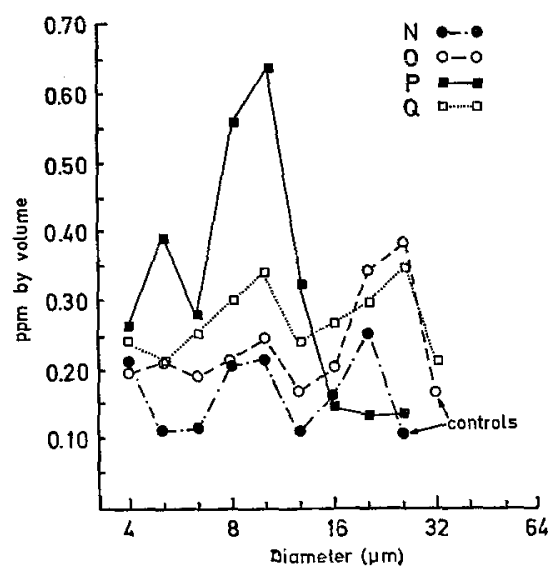

Fig. 1: Size spectrum of particulate material in four 60 ton water columns on Day 18 of an experiment in which $80 \mathrm{ppb}$ and $40 \mathrm{ppb}$ of a water soluble extract of petroleum hydrocarbons were added to column $\mathrm{P}$ and $\mathrm{Q}$ respectively. (After Parsons et al., 1976, modified)

The preferential grazing of large zooplankton on large prey items has been suggested by several authors (e.g. Landry, 1976; Richman \& Rogers, 1969; Frost, 1972). Parsons et al. (1967) showed that Euphausia pacifica was unable to obtain as much ration from a nanoplankton bloom as from a microplankton bloom when both were offered at the same concentration. Similarly, Poulet (1974) showed the Pseudocalanus minutus could not selectively graze phytoplankton larger that $57 \mathrm{\mu m}$ or smaller than ca. $4 \mu \mathrm{m}$, while Frost (1972) showed that the much larger Calanus pacificus obtained a greater ration at the same prey concentration from phytoplankton of $87 \mu \mathrm{m}$ diameter compared with cells of $10 \mu \mathrm{m}$. Thus, while the prey size which any one size of zooplankton can select is quite broad, the general tendency is for all organisms to select the largest cells which they can eat and for the largest zooplankton to be able to select larger cells than those available to the smaller zooplankton.

The feeding of planktivorous predators can be discussed from two recent examples showing size preference. In particular, the feeding of the northern anchovy is of interest because this animal is capable of both raptorial and filter feeding. In studies by Leong \& O'Connel (1969) and O'Connel (1972) it was shown that filter feeding was employed as a method of gathering food only when the concentration of Artemia was less that $7 \%$ of the available biomass of food. Thus the preferred form of feeding for this fish was raptorial feeding for the largest prey items. In another example involving the feeding of young salmonids (LeBrasseur, 1969; Parsons 
\& LeBrasseur, 1970) it was shown that juvenile fish could obtain between 5 and 10 times their hourly ration of food from large calanoid copepods compared with small calanoid copepods, when the two prey items were offered at the same concentration with respect to weight per unit volume. Similar results have been obtained under field conditions where young salmonids have been shown to grow at $4 \%$ day on a natural population of Calanus plumchrus (ca. $2 \mathrm{mg}$ individual wet weight) but to show no growth when fed Corycaeus anglicus (ca. $0.1 \mathrm{mg}$ wt.), at approxiately the same plankton density (Koeller \& Parsons, in press). Thus, the characteristic of raptorial feeding by sight is towards large prey items which presumably more than compensate the hunting animal for the metabolic cost of hunting.

In contrast, the option of sight selection for prey items is not open to the planktivorous "jellies". The feeding of ctenophores in relation to the size of plankton has been the subject of considerable investigation by one of us (Greve, 1971, 1972, 1977) and can be summarized as follows. For large ctenophores of the genus Pleurobrachia, maximum food intake is achieved with small copepods. Large copepods not only are able to tear the tentacles, but even predate upon young stages of Pleurobrachia. Further nauplii of large copepods provide no food to the very young ctenophores thereby preventing population increases. Thus for two different reasons, large copepods are a detriment to ctenophore production while small copepods and their nauplii support these voracious predators.

Table 1

Growth of juvenile salmon and ctenophores in controlled ecosystems (CEPEX)

\begin{tabular}{|c|c|c|c|c|c|}
\hline $\begin{array}{c}\text { Principal } \\
\text { copepod species }\end{array}$ & $\begin{array}{c}\text { Approx. } \\
\text { size } \\
\text { (mg) }\end{array}$ & $\begin{array}{c}\text { Prey } \\
\text { concen- } \\
\text { tration } \\
\text { (number/ } \\
\mathrm{m}^{3} \text { ) }\end{array}$ & Predator & $\begin{array}{c}\text { Duration } \\
\text { of obser- } \\
\text { vations } \\
\text { (days) }\end{array}$ & $\begin{array}{l}\text { Growth } \\
\text { rate of } \\
\text { predator } \\
\text { ( } \% \text { per } \\
\text { day) }\end{array}$ \\
\hline $\begin{array}{l}\text { Paracalanus parvus } \\
\text { Pseudocalanus minutus }\end{array}$ & $\begin{array}{l}0.07 \\
0.12\end{array}$ & $\begin{array}{r}2,200 \\
500\end{array}$ & Pleurabrachia sp. & 10 & 36 \\
\hline $\begin{array}{l}\text { Corycaeus anglicus } \\
\text { Pseudocalanus minutus }\end{array}$ & $\begin{array}{l}0.07 \\
0.12\end{array}$ & 27,000 & $\begin{array}{l}\text { Oncorbynchus keta } \\
\text { (juvenile) }\end{array}$ & 40 & 0 \\
\hline $\begin{array}{l}\text { Calanus plumchrus } \\
\text { Centropages }\end{array}$ & $\begin{array}{l}2.0 \\
0.4\end{array}$ & 2,800 & $\begin{array}{c}\text { Oncorbynchus keta } \\
\text { (juvenile) }\end{array}$ & 40 & 4 \\
\hline
\end{tabular}

A difference in the growth and feeding of young salmonids and the ctenophore Pleurobrachia sp. is shown in Table 1 using data taken from the CEPEX experiments. In the first line it is shown that Pleurobrachia sp. can grow very rapidly on a relatively low concentration of small copepods; in contrast no growth was recorded over 40 days when a high concentration of copepods of a similar size were fed to young salmonids. The young salmonids could however grow on large copepods as illustrated in the last line. Thus the major competition represented here is between successful filter feeding for small copepods by a ctenophore in contrast to successful raptorial feeding for large copepods by juvenile salmonids. In some cases, however, where a 
fish has an ability to change its feeding strategy to filter feed (e.g. O'Connell, 1972; O'Connell \& Zweifel, 1972) it may be able to survive, and even grow, although this may be at a lower growth efficiency.

Apart from these largely experimental observations in support of the two branches of the food web suggested here, there is also some ecological evidence which lends itself in support of this feeding hypothesis. For example, in the seasonal succession of plankton, planktivorous fish and ctenophores, the maximum abundance of planktivorous fish (mainly young salmonids) in the Strait of Georgia (Britist. Columbia) occurs in association with the maximum abundance of the large calanoid copepods, Calanus plumchrus and Calanus glacialis. Small copepods, Calanus pacificus and Pseudocalanus minutus occur during the summer months which is also the time when there is a maximum in the ctenophore Pleurobracbia and the jellyfish Phialidium (Parsons et al., 1970).

\section{DISCUSSION}

The importance of this size-related hypothesis of the pelagic food web lies in its possible predictive use and in the development of management strategy for temperate ocean fisheries. For example, it has been shown that flagellates and other small nanoplankton tend to predominate in deep mixed layers (Parsons \& Takahashi, 1973); thus, a food production favoring carnivorous "jellies" would be favored if climatic conditions caused a maximum in storm activity. This pathways is also favored under conditions of low nutrients and has been found experimentally to result in a ctenophore population within enclosed ecosystems (CEPEX, unpublished results). Since "jellies" do not represent a fishable resource, and their production is to the detriment of young stages of commercially important fish, it may be expected that increased storm activity will depress some fisheries and cause an eventual increase in jellyfish and ctenophore production.

Another possibility is that the known effect of hydrocarbons and other pollutants in stimulating the growth of the nanoplankton may also given rise to an ecosystem predominated by ctenophores and jellyfish. Thus, the release of very small amounts of hydrocarbons in ocean areas where oil exploration is in progress could cause a decrease in the harvestable fisheries of those areas through indirect interference in the natural food web.

Finally, in proposing the hypotheses suggested by our search of the literature we should emphasize that we do not consider our suggestion to be mutually exclusive of other processes tending to increase or decrease world fisheries. Rather, we make these suggestions in order that oceanographers and fisheries scientists may examine current trends in their ecological data which would tend to support or deny our suggestions.

Acknowledgements. The authors are grateful to Mr. P. Koeller (CEPEX) for the enumeration of ctenophores and copepods in Table 1 . The study was in part supported by the National Research Council (Canada) and the National Science Foundation (U.S.A.) under the CEPEX program and by the German/Canadian scientific and technological cooperation programme. 


\section{LITERATURE CITED}

Dickie, L. M., 1973. Management of fisheries; ecological subsystems. Trans. Am. Fish. Soc. 102, 470-480.

Dunstan, W. M., Atkinson, P. P. \& Natoli, J., 1975. Stimulation and inhibition of phytoplankton growth by low molecular weight hydrocarbons. Mar. Biol. 31, 305-310.

Fisher, N. S., 1976. North Sea phytoplankton. Nature, Lond. 259, 160.

Frost, B. W., 1972. Effects of size and concentration of food particles on the feeding behaviour of the marine planktonic copepod Calanus pacificus. Limnol. Oceanogr. 17, 805-815.

Greve, W., 1971. Okologische Untersuchungen an Pleurobrachia pileus 1. Freilanduntersuchungen. Helgoländer wiss. Meeresunters. 22, 303-325.

- 1972. Okologische Untersuchungen an Pleurobrachia pileus 2. Laboratoriumsuntersuchungen. Helgoländer wiss. Meeresunters. 23, 141-164.

- 1977. Interspecific interaction: the analysis of complex structures in carnivorous zooplankton populations. Helgoländer wiss. Meeresunters. 30, 83-91.

Grice, G. D., Reeve, M. R., Koeller, P. \& Menzel, D. W., 1977. The use of large volume, transparent, enclosed sea-surface water columns in the study of stress on plankton ecosystems. Helgoländer wiss. Meeresunters. 30, 118-133.

Koeller, P. \& Parsons, T. R., 1976. The growth of young salmonids in controlled ecosystems. Bull. mar. Sci. (In press).

LeBrasseur, R. J., 1969. Growth of juvenile chum salmon (Oncorbynchus keta) under different feeding regimes. J. Fish. Res. Bd Can. 26, 1631-1645.

Landry, M. R., 1976. The structure of marine ecosystems: an alternative. Mar. Biol. 35, 1-7.

Leong, R. J. H. \& O'Connell, C. P., 1969. A laboratory study of particulate and filter feeding of northern anchovy (Engraulis mordax). J. Fish. Res. Bd Can. 26, 557-582.

Malone, T. C., 1971. The relative importance of nanoplankton and netplankton as primary producers in the California Current system. Fish. Bull. U.S. 69, 799-820.

O'Connell, C. P., 1972. The interrelation of biting and filtering in the feeding activity of the northern anchovy (Engraulis mordax). J. Fish. Res. Bd Can. 29, 285-293.

- \& Zweifel, J. R., 1972. A laboratory study of particulate and filter feeding of the Pacific mackerel, Scomber japonicus. Fish. Bull. U.S. 70, 973-981.

Parsons, T. R., 1974. Controlled ecosystem pollution experiment (CEPEX) Environm. Conservation $1,224$.

- \& LeBrasseur, R. J., 1970. The availability of food to different trophic levels in the marine food chain. In: Marine food chains, Ed. by J. H. Steele. Oliver \& Boyd, Edinburgh, 325-343.

- \& Takahashi, M., 1973. Environmental control of phytoplankton cell size. Limnol. Oceanogr. 18, 511-515.

- LeBrasseur, R. J. \& Barraclough, W. E., 1970. Levels of production in the pelagic environment of the Strait of Georgia, British Columbia: A Review. J. Fish. Res. Bd Can. 27, $1251-1264$.

- LeBrasseur, R. J. \& Fultoil, J. D., 1967. Some observations on the dependence of zooplankton grazing on the cell size and concentration of phytoplankton blooms. J. Oceanogt. Soc. Japan 23, 10-17.

- Li, W. K. W. \& Waters, R., 1976. Some preliminary observations on the enhancement of phytoplankton growth by low levels of mineral hydrocarbons. Hydrobiologia, 5, 85-89.

Poulet, S. A., 1974. Seasonal grazing of Pseudocalanus minutus on particles. Mar. Biol. 25, 109-123.

Richman, S., \& Rogers, J. M., 1969. The feeding of Calanus belgolandicus on synchronously growing populations of the marine diatom Ditylum brightwellii. Limnol. Oceanogr. 14, $701-709$.

Ryther, J. H., 1969. Photosynthesis and fish production in the sea. Science, N. Y. 166, 72-76.

Semina, H. J., 1972. The size of phytoplankton cells in the Pacific Ocean. Int. Revue ges. Hydrobiol. 57, 177-205. 
Smith, J., 1968. Torrey Canyon - pollution of marine life. Report by the Plymouth Laboratory of the Marine Biological Association of the U.K., London. Cambridge Univ. Press, London, $196 \mathrm{pp}$.

Thomas, W. H. \& Seibert, D. L. R. Effects of copper on enclosed marine phytoplankton assemblages: taxonomic composition of the phytoplankton. Bull. mar. Sci. (In press).

Wangersky, P. J., 1977. The role of particulate matter in the productivity of surface waters. Helgoländer wiss. Meeresunters. 30, 546-564.

First author's address: W. Greve

Biologische Anstalt Helgoland (Meeresstation)

D-2192 Helgoland

Federal Republic of Germany 